\title{
VIRTUAALINEN TYÖPAJA OPETTAJAN AMMATILLISEN KEHITTYMISEN TUKENA
}

Kirjoituksia koulutuskokemuksista -kirjoituskilpailun II palkinnon saanut Essi Ryyminin ja Kati Korhosen teksti kertoo opettajien täydennyskoulutuksen innovaatiosta, virtuaalisesta työpajasta. Se tarkoittaa opettajien yhteisöllistä ja ongelmalähtöistä tiedonrakenteluprosessia, jota ohjataan verkko-oppimisympäristön keskustelualueella. Virtuaalisen työpajan tavoitteena on tuottaa yhdessä uutta tietoa ja käytännössä sovellettavia toimintamalleja tutkivaan verkko-oppimiseen.

\section{ESSI RYYMIN JA KATI KORHONEN}

$\mathrm{I}$ nnovaatio on osa ITCOLE-projektissa (http:/ /www.euro-cscl.org/site/itcole) kehitettyä peruskoulujen ja lukioiden opettajien verkko-oppimisen täydennyskoulutus- ja konsultointimallia (Haatainen ja Korhonen 2002; Ryymin ja Korhonen 2003). Koulutus- ja konsultointimallin tavoitteena on edistää pedagogisesti korkeatasoista teknologian käyttöä tavallisissa kouluissa. Mallin periaatteita ovat ongelmalähtöisyys, osallisuus ja yhteisöllisyys: opettajia ohjaava kouluttaja toimii oppimiskumppanina aidoissa oppimistilanteissa ja opettajat työskentelevät yli koulurajojen muodostetuissa verkostoissa. Mallin mukaisella täydennyskoulutuksella halutaan edistää tavoitteellisesti opettajien valmiuksia toteuttaa ja jakaa uusia verkko-oppimisen käytänteitä omassa toimintaympäristössään muutosvastarinnasta huolimatta. Toiminnalla tuetaan verkostoitunutta asiantuntijuutta, joka perustuu opettajien muodostaman verkoston jaettuun eikä vain yksilölliseen osaamiseen.

\section{YHTEISÖLLISIÄ RATKAISUJA KÄYTÄNNÖN ONGELMIIN}

Täydennyskoulutuksen aikana opettajat kehittävät ammatillista osaamistaan sekä tiedollisesti että käytännössä työtehtävissään kokeillen ja kehittäen. Koulutuksen keskeisiä sisältöjä ovat tutkiva oppiminen, verkko-oppimisprosessin suunnittelu ja ohjaaminen, verkko-oppimisen käytännön toteutus, omien pedagogisten käytänteiden mallintaminen ja arvioiminen, muutosjohtaminen sekä osaamisen jakaminen, muun muassa niveltämällä toiminta koulun opetussuunnitelma- ja tietostrategiatyöhön. Koulutus kestää noin kolme kuukautta ja se sisältää lähipäiviä, koulukohtaista konsultointia ja verkkotyöskentelyä.

Virtuaalisia työpajoja organisoidaan koulutuksen siinä vaiheessa, kun opettajat soveltavat uutta tietoa omassa työssään eli ohjaavat ensimmäistä kertaa tutkivan verkko-oppimisen projekteja. Toteuttaessaan tutkivaa verkko-oppimista opettajat kohtaavat sellaisia monimutkaisia ja autenttisia ongelmia, joita eivät pysty yksin ja perinteisin keinoin ratkaisemaan. Virtuaalisessa työpajassa edistetään näiden ongelmien ratkaisua yhteisöllisyyden ja ajatustyypeillä (engl. thinking types) tuetun, ohjatun tiedonrakentelun keinoin.

Virtuaalisessa työpajassa työskentely tapahtuu verkko-oppimisympäristön keskustelualueella ajatustyyppien avulla. Työpajaan on mahdollista osallistua tietokoneelta, jossa on verkkoyhteys. Työpajaan osallistuvat opettajat, kouluttaja ja käsiteltävän aihepiirin asiantuntija. Virtuaalinen työpaja toteutetaan yhden iltapäivän aikana ja se kestää noin kaksi tuntia. Työpajan tavoitteena on rakentaa uutta tietoa ja käytännössä sovellettavia toimintamalleja tutkivaan verkkooppimiseen. Tiedonrakentelulla tarkoitetaan yhteisöllistä työskentelyä käsitteellisten luomusten 
(esim. toimintamallien ja teorioiden) kehittämiseksi. (Hakkarainen ym. 2000, 274.) Keskeistä ovat tiedonrakentelussa muodostuvat ratkaisut ongelmaan, niiden yhteisöllinen käsittely sekä ryhmän yhteisen identiteetin ja tietovarannon rakentuminen. Yhteisen tiedon tuottamisessa ei siis pyritä merkityksettömään ja määrättömään tietotulvaan (engl. information), esimerkiksi loputtomiin tietolähteisiin, vaan hallittavaan, omassa prosessissa tuotettuun tietovarantoon (engl. knowledge). (McConnell 2001; Mahlamäki-Kultanen 2001.) Ongelmien tuominen oppimiskumppaneiden eli opettajien, kouluttajan ja asiantuntijan yhteiseen tiedonrakenteluun auttaa myös koulutuksen järjestäjää havaitsemaan opetuskulttuurin muutoksen esteenä olevia autenttisia ongelmia.

\section{VIRTUAALISEN TYÖPAJAN PEDAGOGISET LÄHTÖKOHDAT}

Virtuaalisen työpajan pedagogisia periaatteita ovat yhteisöllinen ja ongelmalähtöinen oppiminen (Lipponen 1997; Vahtivuori, Wager ja Passi 1999; Hakkarainen, Lipponen ja Lonka 2000; Tella, Vahtivuori, Vuorento, Wager ja Oksanen 2001) ja tiedonrakentelu vuorovaikutuksessa (Scardamalia ja Bereiter 1992; 1994). Työpajan toimintamalli on kehitelty tutkivan oppimisen mallin (Hakkarainen ym., 2000) ja aiempien koulutuskokemusten (Haatainen ja Korhonen 2002) pohjalta. Kokemusten mukaan opettajat eivät välttämättä hyödy viikkoja kestävästä verkkokeskustelusta. Kuitenkin siinä vaiheessa, kun opettajat soveltavat uusia pedagogisia käytänteitä omassa toimintakontekstissaan, heille syntyy tarve löytää ratkaisuja uudenlaisiin ongelmiin.

Koska täydennyskoulutuksen tavoitteena on kehittää opettajien tutkivan verkko-oppimisen osaamista, on myös tärkeää tuottaa opettajille omakohtainen kokemus tiedonrakentelusta verkossa. Näin syntyi idea intensiivisestä ongelmanratkaisuprosessista verkossa, jota tuetaan keskustelualueen ajatustyypeillä ja jossa ratkaistaan opettajille ajankohtainen, autenttinen ongelma.

Nevgin ja Tirrin (2001) tutkimuksessa todetaan, että aikuisopiskelijoiden mielestä verkossa oppimista estäviä tekijöitä ovat yksinäisyys, vuorovaikutuksen, henkilökohtaisen palautteen ja tuen puute sekä vaikeudet ajanhallinnassa ja opintojen suunnittelussa. Virtuaalisen työpajan toimintamallissa kahden tunnin tiiviillä työskentelyllä helpotetaan ajanhallintaa ja tehostetaan opettajien välistä vuorovaikutusta sekä varmistetaan, että opettajat saavat tarvittavan tuen verkkotyöskentelyn aikana.

\section{KUINKA VIRTUAALISESSA TYÖPAJASSA TOIMITAAN?}

Työpaja on jaettu kolmeen vaiheeseen, joita ovat: 1) kartoittava tiedonrakentelu, 2) syventävä tiedonrakentelu ja loppuyhteenveto sekä 3) päätös ja arviointikeskustelu.

Työpajan ensimmäisessä vaiheessa esitetään kaikille yhteinen ratkaistava ongelma ja aloitetaan tiedonrakentelu. Tiedonrakentelun ensimmäinen vaihe on erilaisten selitysten etsimistä yhteiseen ongelmaan (esim. Miksi oppilaiden yksilölliset ongelmanratkaisuprosessit eivät ole käynnistyneet?). Tiedonrakenteluvaiheen jälkeen kouluttaja tekee ensimmäisen yhteenvedon.

Ensimmäisen tiedonrakenteluvaiheen yhteenvedon perusteella kouluttaja esittää uuden, syventävän ongelman, jolla hän pyrkii ohjaamaan opettajia uusien toimintamallien luomiseen. (esim. Miten opettaja saisi oppilaat valitsemaan hyvät tutkimusongelmat ja jaettua heidät mielekkäästi pienryhmiin?). Toisen tiedonrakenteluvaiheen aikana opettajat luovat yhdessä uusia toimintamalleja, joiden avulla ongelma voidaan ratkaista käytännössä. Toinen tiedonrakenteluvaihe päättyy kouluttajan ja opettajien loppuyhteenvetoon uusista toimintamalleista.

Virtuaalisen työpajan lopuksi kouluttaja ohjaa opettajat yhteisölliseen palautekeskusteluun, jossa reflektoidaan virtuaalisen työpajan toteutusta ja johtopäätöksiä. Virtuaalisen työpajan jälkeen ryhmien johtopäätöksistä tehdään yhteenveto, jossa uusi tieto ja toimintamallit ryhmitellään loogisesti ja julkaistaan verkko-oppimisympäristössä. Näin eri ryhmien johtopäätökset ovat kaikkien koulutukseen osallistuneiden käytössä.

\section{VIRTUAALISEN TYÖPAJAN OHJAAMINEN}

Virtuaalisen työpajan organisoi ja ohjaa kouluttaja. Ennen virtuaalista työpajaa opettajat kuvailevat käytännön työssään kohtaamiaan haasteita ja valitsevat ajankohtaisen ongelman, johon kaipaavat ratkaisua edistäessään tutkivaa verkko-oppimista. Kouluttaja muotoilee tarvittaessa valitun ongelman kysymykseksi. Kouluttaja voi liittää ongelmaan myös tarinan, tapausesimerkin, 
joka helpottaa opettajien eläytymistä ongelmanratkaisuun. ITCOLE-projektissa virtuaalisia työpajoja toteutettiin esimerkiksi seuraavista opettajien toivomista aiheista: "Tutkivan oppimisen prosessin ohjaaminen verkossa ja luokassa”, "Tieto- ja viestintätekniikan opetuskäytön edistäminen ja muutosvastarinta”, "Syvenevän tutkimus- ja tiedonrakenteluprosessin ohjaaminen" ja "Oppilaiden arviointi tutkivan oppimisen prosessissa".

Vygotsky (1987) korostaa oppimisessa ongelman koon kohtuullisuutta ja ohjaajan saatavilla oloa. Virtuaalisessa työpajassa ratkaistava ongelma valitaan opettajien itse esittämistä ongelmista. Lisäksi, ennen työpajaa, opettajat joko perehtyvät ongelman aihepiiriä käsittelevään artikkeliin tai osallistuvat luennolle; näin varmistetaan, että opettajilla on ongelmanratkaisussa tarvittavia yhteisiä käsitteitä sekä ajattelun ja analyysin välineitä. Opettajat jaetaan 6-10 hengen ryhmiin ohjauksen ja samanaikaisen verkkovuorovaikutuksen onnistumiseksi. Ryhmät muodostetaan siten, että opettajat ovat opetuskokemukseltaan ja verkkopedagogiselta osaamiseltaan erilaisia. Heterogeenisessä ryhmässä muodostuu enemmän erilaisia näkökulmia ratkaistavaan ongelmaan.

Virtuaalisen työpajan aikana kouluttaja ohjaa tiedonrakentelua kysymyksillä, kannustamalla ja toimimalla esimerkkinä ajatustyyppien käytössä. Kouluttaja tarvitsee taitoa ohjata vuorovaikutusta verkossa: opettajien intuitiivisille ja spontaaneille käsityksille on tarjottava tilaa ja heitä on rohkaistava niiden esittämiseen. Kouluttajan on huolehdittava myös siitä, että tiedonrakenteluvaiheesta siirrytään johtopäätösten tekemisen vaiheeseen. Tämä edellyttää kouluttajalta tilanneherkkyyttä, vaikka toimitaankin emotionaalisten vihjeiden osalta niukassa verkkoympäristössä. Ohjausprosessi edellyttää kouluttajalta reaaliaikaista reflektiota omista ohjausmenetelmistään.

Kouluttajan tehtäviä virtuaalisessa työpajassa voidaan verrata yleisiin verkko-opettajan tehtäviin. (Tella ym. 2001, 221-250.) Kouluttajan tehtävänä on 1) ohjata virtuaalisen työpajan aiheen ja ratkaistavien ongelmien suunnittelua, 2) hankkia aihepiirin erityisasiantuntija, 3) ohjata opettajia työpajan toimintatavoissa, 4) ohjata opettajia verkko-oppimisympäristön teknisessä käytössä, 5) ohjata tiedonrakentelua sekä motivoida ja kannustaa osallistujia, 6) ohjata yhteenvedon tekemistä tiedonrakentelun johtopäätöksistä ja 7) ohjata yhteisöllistä palautekeskustelua.

Opettajien ja kouluttajan lisäksi työpajaan osallistuu aihepiirin asiantuntija (esim. yhteisöllinen oppiminen, työelämän muutosjohtaminen, verkkoympäristöjen suunnittelu, oppimisen arviointi jne.). Asiantuntijan tehtävänä on tuoda tiedonrakenteluun tutkimustietoa ja teoreettista ymmärrystä, jonka avulla opettajat voivat jäsentää omia arkisia käsityksiään ja siten tarkastella ja kehittää omaa toimintaansa.

\section{AJATUSTYYPIT TIEDONRAKENTELUN TUKENA}

Virtuaalisessa työpajassa ongelmanratkaisua ja uuden tietovarannon rakentamista tuetaan ajatustyypeillä. Ne ovat viestityyppejä, jotka on nimetty ongelmanratkaisuprosessille tyypillisen vuorovaikutuksen ja tiedonrakentelun elementtien

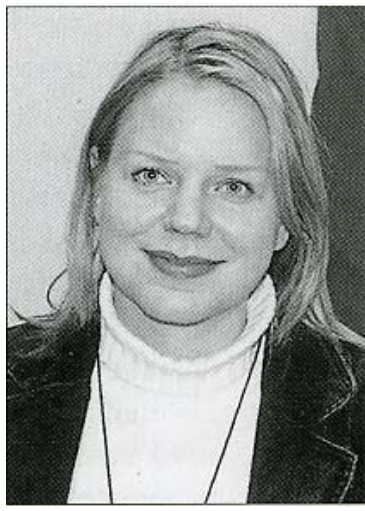

Essi Ryymin

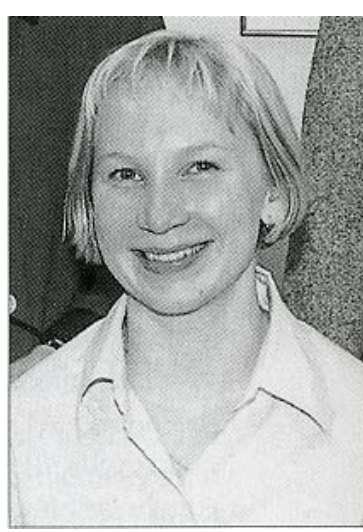

Kati Korhonen mukaan (Scardamalia ja Bereiter 1992; 1994; Lipponen ja Hakkarainen 1998). Virtuaalisessa työpajassa käytettyjä ajatustyyppejä ovat: ongelma, oma selitys, syventävää tietoa, prosessin arviointi, yhteenveto ja työn organisointi. Ajatustyypit havainnollistavat ongelmanratkaisuprosessin etenemistä tarjoamalla välineitä kognitiivisen toiminnan jäsentämiseen korvaamatta kuitenkaan osallistujien omia kognitiivisia ponnisteluja. (Lipponen ja Hakkarainen 1998.).

Toiminnan tukeminen ajatustyyppien avulla liittyy ihmisen ajattelun kognitiivisen tutkimuksen tuloksiin 15-20 vuoden ajalta. Ajatustyyppejä on käytetty aiemmin muun muassa CSILE-järjestelmässä (ks. esim. Scardamalia ja Bereiter 1992; 1994; Lipponen ja Hakkarainen 1998). Tiedonrakentelu verkko-oppimisympäristön julkisessa tietokannassa muuttaa erilaisen asiantuntijuuden omaavien osallistujien ajatteluprosessit avoimiksi ja havaittaviksi. Yhteisön on helpompi käsitellä ja jäljitellä kirjoitettuja kuin suullisesti esitettyjä ajatuksia. Näin yhteisön jäsenten on mahdollista 
omaksua kehittyneitä kognitiivisia käytäntöjä monimutkaisten ongelmien ratkaisemiseksi. (Scardamalia, Bereiter, McLean, Swallow ja Woodruff 1989; Lipponen ja Hakkarainen 1998, 8.) Orrillin (ks. Mahlamäki-Kultanen 2001, 20) tutkimuksissa ongelmalähtöisistä oppimisympäristöistä on ilmennyt, että ajatustyypin merkitseminen viestiin ohjaa oppijoita tietoiseen työskentelyyn ja dokumentoi oppimisprosessia. Ajatustyypin merkitseminen tuo myös esille sen, että oppimisprosessi etenee oppijoiden omalla lähikehityksen vyöhykkeellä, jolloin se tukee oppimista optimaalisella tasolla.

Virtuaalisessa työpajassa käytetyt ajatustyypit on muokattu ITCOLE-projektissa opettajien, projektin tutkijoiden ja kouluttajien yhteistyönä. Ajatustyyppien käytöllä on työpajassa kaksi merkitystä. Toisaalta niiden avulla jäsennetään opettajien omaa ongelmanratkaisuprosessia, toisaalta opettajat harjoittelevat niiden käyttöä ohjatakseen oppilaitaan tiedonrakenteluun.

\section{OPETTAJIEN KOKEMUKSIA}

ITCOLE-projektissa opettajilta pyydettiin palautetta virtuaalisista työpajoista ja niissä syntyneen tiedon ja toimintamallien soveltuvuudesta omaan työhön. Opettajat kertoivat, että työpajojen ongelmat olivat hyvin rajattuja, ajankohtaisia ja merkityksellisiä oman työn kannalta. Opettajat kokivat, että tiedonrakentelu toi esiin erilaisia näkökulmia ratkaistavaan ongelmaan ja uusia ideoita omaan opetukseen. Opettajat kokivat työpajan myös ruokkivan omaa ajattelua ja tukevan oppimisprojektin suunnittelua ja käytännön toteutusta.

Ensimmäistä kertaa tutkivaa verkko-oppimista toteuttavat opettajat mainitsivat tärkeäksi sen, että he saivat omakohtaisen kokemuksen tiedonrakentelusta verkossa. Opettajat kertoivat saaneensa työpajasta hyviä vinkkejä opetuksen organisointiin ja oppilaiden ohjaukseen verkossa. Tärkeää oli myös se, että opettajat kokivat saaneensa virtuaalisesta työpajasta rohkeutta käyttää verkko-oppimisympäristöä omassa opetuksessaan. Opettajat kokivat, että työpajan rajattu aika motivoi osallistumaan tiedonrakenteluun ja ajatustyyppien käyttö oli haastavaa. Opettajat pohtivat palautteissaan paljon sitä, miten oppilaita tulisi ohjata ajatustyyppien käyttöön ja miten ajatustyyppien käyttöä voisi harjoitella yhdessä.
Tekniset ongelmat ja hitaat verkkoyhteydet haittasivat muutamien opettajien osallistumista täysipainoisesti virtuaaliseen työpajaan. Nevgin ja Tirrin (2001) tutkimuksen mukaan tekniset ongelmat koetaan yhdeksi keskeiseksi esteeksi verkossa oppimiseen. Tekniset ongelmat olisikin eliminoitava mahdollisimman tarkasti etukäteen, samoin kuten olisi suunniteltava, miten toimitaan silloin kun ongelmia ilmenee työpajan aikana.

\section{VIRTUAALISEN TYÖPAJAN POHDINTAA}

\section{Verkostoituminen opettajan ammatillisen kehittymisen voimavarana}

Launis ja Engeström (1999, 64, 73-75) kirjoittavat, että asiantuntijuus on yhä enemmän verkostojen ja organisaatioiden kykyä ratkaista yhdessä uusia ja muuttuvia ongelmia. Ratkaisut opettajien asiantuntijuuden kehittämiseen eivät löydy koulutuksen suunnittelijoiden pöydiltä, vaan opetustyön arkipäivän analyyseista ja työn kehittämisen kokeiluista - työelämässä vallitsevien rakenteiden ja toimintatapojen tietoisesta muuttamisesta.

Virtuaalinen työpaja luo opettajien keskinäiselle verkostoitumiselle selkeän tehtävän ja merkityksen; niiden ongelmien ratkaisemisen, joita oman opetustyön uudistaminen tuo esiin. Työpajaa sovelletaan erityisesti tutkivan verkko-oppimisen käytännön toteuttamisen tukena. Koiviston, Kylämän, Listenmaan ja Vainion (2002) mukaan juuri virtuaaliopetuksen vaikutuksesta syntyy uudenlaisia haasteita opettajuudelle niin paljon, ettei yksittäinen työntekijä pysty niihin vastaamaan, vaan tarvitaan usean opettajan osaamisen yhdistämistä tiimityöskentelyksi. Virtuaalinen työpaja pyrkii kuitenkin tiimityötä avoimempaan ja verkostoituneempaan asiantuntijuuden jakamiseen. Virtuaalisessa työpajassa tietoa rakentelevat eri kouluissa työskentelevät, ammatilliselta osaamiseltaan eritasoiset opettajat, kouluttajat sekä asiantuntijat, jotka eivät työskentele perinteisessä mielessä keskinäisissä tiimeissä.

Tiedonrakentelun toteuttaminen virtuaalisessa työpajassa luo suuren joukon päällekkäisiä lähikehityksen vyöhykkeitä. Ne auttavat opettajaa löytämään toimintamalleja, joiden seuraaminen on hänen kognitiivisen kehityksensä näkökulmasta mahdollista. Kognitiivinen tutkimus tukee olettamusta, jonka mukaan asiantuntijuus kehittyy nimenomaan eritasoisten asiantuntijoi- 
den muodostamissa yhteisössä (Lipponen ja Hakkarainen 1998, 8-9).

Virtuaalinen työpaja edistää opettajien ammatillista kehittymistä koulujen rajat ylittävän verkoston, oppimiskumppanuuden ja yhteisöllisen reflektion keinoin. Bransfordin, Brownin ja Cookingin (1999, 16-17) mukaan opettajien uuden teknologian pedagoginen käyttöönotto ja ammatillinen kehittyminen edellyttävät opettajien, rehtoreiden, oppilaiden, yliopistojen ja ohjelmistoyritysten välistä verkostoitumista ja kriittistä kumppanuutta. Myös Hakkaraisen ja Järvelän (1999, 256) mukaan keskeisenä strategiana koulun pedagogisissa kehityshankkeissa tulisi olla sellaisen yhteisön rakentaminen, joka kytkee erilaiset asiantuntijakulttuurit koulun oppimisprojektien tueksi. Tutkijat (emt.) arvioivat, että opetus- ja oppimiskäytäntöjen kehittäminen vastaamaan tietoyhteiskunnan haasteisiin ei ehkä ole mahdollista ilman laajennettujen oppimisyhteisöjen ja verkostojen muodostamista.

Korhonen (2003) on tutkinut yhteisöllisen kontekstin merkitystä aikuisopiskelijoiden verkkooppimisympäristössä. Verkko-opiskelijoiden kokema oppimisympäristö koostuu opiskelijan omasta, koulutuksen järjestäjän ja opiskelijoiden yhdessä rakentamasta yhteisöllisestä kontekstista. Opiskelijat kokivat, että yhteisöllinen konteksti avasi erilaisia näkökulmia käsiteltävään tietoon ja rikastutti oppimista. Korhosen (emt., 212) mukaan uudet oppimisen teknologiat tukevat aikuisen oppimista parhaiten silloin, kun niitä käytetään ryhmässä tapahtuvan käsitteellistämisen ja jaetun asiantuntijuuden kehittymisen tukena eikä kaiken vuorovaikutuksen korvaajana etäopiskelussa. (vrt. Hakkarainen 2001, 34-35.)

\section{INTENTIONAALISUUDEN MERKITYS OPETTAJAN \\ AMMATTIKEHITYKSELLE}

Ruohotie (2003, 9-10) tarkastelee ammatillista huippuosaamista käsittelevässä artikkelissaan intentionaalisuutta osana ammattispesifistä osaamista. Erilaisten oppimisstrategioiden soveltaminen voi auttaa onnistumaan oppimistehtävässä, mutta ei takaa, että oppija todella pohtii ajatuksiaan. Jotta oppijan ajattelussa tapahtuisi intentionaalinen, käsitteellinen muutos, oppijan tulisi ensiksikin tiedostaa muutostarpeensa ja se, mitä tulee muuttaa (metakognitiivinen ehto). Oppijan tulisi myös haluta muutosta, hänen tulisi mieltää muutos henkilökohtaisena tavoitteena (volitionaalinen ehto) ja kyetä säätelemään, suunnittelemaan, tarkkailemaan ja arvioimaan omaa muutosprosessiaan (itsesäätelyehto). (Ruohotie 2003; ks. myös Luque 2003.) Intentionaalinen muutos on todennäköistä silloin, kun oppijalla on vahva ammattispesifinen osaaminen ja vahvat itsesäätelytaidot. Muutosta edistää myös se, että oppijan tavoitteena on kasvattaa kompetenssiaan ja hän kokee tehtävän haasteelliseksi ja mielekkääksi. Muutoksen kannalta on merkityksellistä, että tehtävä ei uhkaa oppijan itseluottamusta, tehokkuususkomuksia tai minäarvostusta.

Poikelan $(2003,220)$ mukaan ongelmalähtöisessä oppimisessa tavoitteena on ohjata ongelmanratkaisua niin, että oppija kykenee integroimaan teoreettista ja käytännöllistä tietoa sekä yksilöllisissä että ryhmässä jaetuissa tiedon muodostuksen prosesseissa. Integraation tuloksena syntyy kokemuksellista tietoa, joka on luonteeltaan pysyvämpää kuin muistamiseen tai emotionaalisiin elämyksiin liittyvä tieto. Teorian ja käytännön välinen liike tuottaa kokemuksellista tietoa, jota pystyy luomaan ainoastaan oppija itse. Oppija on aktiivisessa roolissa. Myös Nevgin ja Tirrin $(2001,148)$ tutkimus osoittaa, että aikuisopiskelijoiden mielestä opiskelijan intentionaalisuus ja aktiivisuus edistävät parhaiten oppimista verkossa.

Virtuaalista työpajaa ei voida tarkastella vain yhteisöllisen oppimisen näkökulmasta, sillä tärkeitä tekijöitä ovat myös opettajan oma intentio ja halu ammatilliseen kehittymiseen. Koulutukseen hakeutuneet opettajat ovat tiedostaneet muutostarpeen omassa työssään. Täydennyskoulutus ja virtuaalinen työpaja tukevat opettajia heidän omien ammattikäytänteidensä kehittämisessä. Työpajassa tarjotaan opettajille tilaisuus käytännöllisen tiedon ja teoriatiedon integroimiseen yhteisöllisessä tiedonrakentelussa. Tämä edistää opettajan oman, kokemuksellisen tiedon syntymistä.

\section{VUOROVAIKUTUKSESSA KEHITTYMINEN HAASTEELLISTA}

Aarnion ja Enqvistin (2001, 11-12) mukaan verkko toimintaympäristönä eroaa perinteisestä opetuksen kontekstista niin paljon, etteivät opettajien perinteiset toimintamallit riitä tulokselliseen oppimiseen verkossa, vaan tarvitaan uusia tapoja toimia. Virtuaalisessa työpajassa on kyse uu- 
den pedagogisen toimintamallin, tutkivan verkko-oppimisen, soveltamisesta käytännössä.

Virtuaalinen työpaja on koulutuksellinen ratkaisu, jolla pyritään edistämään opettajien ammatillista kehittymistä työelämässä. Ruohotien (2000, 9) mukaan ihmisen ammatillinen kasvu on jatkuva oppimisprosessi, jonka kautta yksilö hankkii elämänuransa aikana niitä tietoja, taitoja ja kykyjä, joita hyödyntämällä hän vastaa muuttuviin ammattitaitovaatimuksiin. Järvisen (1999, 259) mukaan opettajan ammatillisen kehitysprosessin tavoitteena tulisi olla reflektiivinen ammattikäytäntö: yksilön ja työyhteisön toiminnan kriittisen pohdinnan tavoitteena on käytänteiden kehittäminen. Järvisen (emt.) tutkimukset ovat paljastaneet, että opettajankoulutuksen ja työelämän välissä on ongelmallinen vaihe, jonka aikana opettaja saattaa lopettaa oman työnsä kehittämisen. Virtuaalisessa työpajassa opettajia ohjataan uuteen ammattikäytäntöön, jota he voivat soveltaa työnsä kehittämisessä täydennyskoulutuksen jälkeenkin.

Virtuaalisessa työpajassa harjoitellaan yhdessä uusia verkko-oppimisen käytänteitä: yhteisöllistä tiedonrakentelua, avointa osaamisen jakamista ja vuorovaikutusta verkossa. Ruohotien (2000, 219) mukaan vuorovaikutuksessa kehittyminen vaatii yksilöltä valmiutta pitää toista ihmistä oman oppimisensa ja kehittymisensä lähteenä. Tämä edellyttää opettajilta usein oman oppimiskäsityksen tarkastelua. Ojasen (1998, 225) ja Rajalan (2002) mukaan opettajilla ei ole viitekehystä toistensa tukijana toimimiseen eikä heillä ole toimivia yhteisöllisiä käytänteitä. Opettajat ovat individualistisen työorientaationsa vankeja. Tämä ilmenee myös siinä, ettei opettajilla ole menetelmiä yhteisöllisten käytänteiden ohjaamiseen omassa opetuksessaan. Lakkalan, Lallimon ja Rahikaisen (2003) ITCOLE-projektiin liittyvän tutkimuksen mukaan opettajien on erityisen vaikeaa kehittää ja toteuttaa sellaisia verkko-oppimisen käytänteitä, jotka tukevat aidosti oppilaiden kollektiivista työskentelyä ja tietoisesti yhteiseen tavoitteeseen pyrkimistä.

\section{KOULUTTAJA}

\section{OPPIMISKUMPPANINA}

Hargreaves, Earl, Moore ja Manning (2001, 195199) kirjoittavat, että opettajan on älyllisesti ja emotionaalisesti erittäin haastavaa oppia opettamaan toisin, kuin häntä itseään on opetettu. Tut- kijoiden (emt.) mukaan opetuskulttuurin muutos edellyttää opettajien tukemista käytännön yksityiskohdissa. Opettajat tarvitsevat tukihenkilön ohjausta uusien opetusmenetelmien todeksi tekemisessä. Myös Järvisen (1990; 1999, 259) mukaan opettajan ammatilliselle kehitykselle olisi työelämässä oltava tukija, jolla on professionaalinen ja konsultatiivinen orientaatio aikuisen oppimisen tukemiseen.

Virtuaalisessa työpajassa opettajien oppimiskumppanina ja tukihenkilönä toimii kouluttaja. Kouluttajan toiminta ei kuitenkaan edusta perinteistä aikuisoppijan konsultointia. Kouluttaja on opettajan tasaveroinen oppimiskumppani, joka on osallinen yhteisölliseen tiedonrakenteluprosessiin. Kouluttajan on kyettävä pitämään opettajia oman oppimisensa lähteenä ja tavoiteltava vuorovaikutuksessa tapahtuvaa kehittymistä suostumalla keskinäiseen riippuvuuteen. Myös kouluttaja arvioi omia käsityksiään ja rakentaa uutta ymmärrystä opettajien ja asiantuntijan mahdollistamissa lähikehityksen vyöhykkeissä. Kouluttaja paitsi ohjaa opettajia myös toimii itse intentionaalisena oppijana. Kouluttaja ei ole tukihenkilö, joka ohjaa opettajat tekemään uudet menetelmät todeksi, vaan hän on sen yhteisöllisen ongelmaratkaisuprosessin ohjaaja ja osallinen, jossa luodaan uusia ratkaisuja käytännön toteutukseen.

\section{LOPUKSI}

Virtuaalinen työpaja soveltuu tukemaan pitkäkestoista täydennyskoulutusta, joka tähtää uudistavaan oppimiseen (Mezirow 1996) ja opettajan työkäytänteiden muutokseen. Se soveltuu erityisesti työn ohella tapahtuvaan ongelmanratkaisuun ja osaamisen jakamiseen siinä vaiheessa, kun käytännön työn uudistaminen on konkreettisesti aloitettu ja ensimmäiset ongelmat kaipaavat ratkaisua.

Virtuaalisessa työpajassa ajatustyypeillä tuettu tiedonrakentelu tähtää ajallisesti rajattuun, tehokkaaseen ja ohjattuun ongelmanratkaisuun, vaikka sen käynnistämä reflektioprosessi jatkuu luonnollisesti työpajan jälkeenkin. Työpajojen lisäksi opettajille on tarjottava mahdollisuus kiireettömään, avoimeen dialogiin ja muutoksen pohdiskeluun ilman tiukkaa aikataulua. Onnistunut täydennyskoulutus tarjoaa monipuolisia toimintatapoja ja erilaisia ohjausmenetelmiä koulutusprosessin eri vaiheissa. 
Virtuaalisen työpajan ideaa on mahdollista soveltaa monilla eri tavoilla koulutuksen kaikilla tasoilla ja se on vapaa jatkokehittelylle. Se tarjoaa yhden mielekkään pedagogisen käytänteen verkko-oppimisen hyödyntämiseen täydennyskoulutuksessa. Verkkoympäristöjen innovatiivinen käyttö, kuten virtuaalinen työpaja, tuo erityisesti opettajien täydennyskoulutukseen uuden ulottuvuuden, sillä se mahdollistaa opettajien keskinäinen verkostoitumisen ja tekee koulurajat ylittävän osaamisen jakamisen sekä työkäytänteiden uudistamisen näkyväksi. Tämä edistää osaltaan koulujen käytäntöyhteisöjä (mm. Wenger 1998) kehittymään kohti verkostoituneita, innovatiivisia tietoyhteisöjä (Hakkarainen, Paavola ja Lipponen 2003), joissa osaaminen ja innovaatiot liikkuvat esteettä. Osaamisen verkostot raikastavat koulun roolia proaktiivisena ja uutta luovana toimijana tietoyhteiskunnassa sen sijaan, että koulu pysyttäytyy osaamisvaatimuksiin hitaasti reagoivana muutosvastarintamana. Uudistumaton, "pinttyneiden toimintamallien” (Lauriala 2000, 90) koulu jää tieto- ja osaamisyhteiskuntakeskustelussa ulkopuoliseksi, mikä saattaa tarkoittaa sitä, että muut kuin opetus- ja kasvatusalan asiantuntijat alkavat määritellä koulun tehtävää ja toimintatapoja.

\section{LÄHTEET}

Aarnio, H. ja Enqvist, J. (2001). Dialoginen oppiminen verkossa - DIANA-malli ammatillisen osaamisen rakentamiseen. Opetushallitus.

Bransford, J.D., Brown, A.L. ja Cooking, R.R. (1999). How people learn: Brain, Mind, Experience and School. [http://books.nap.edu/ html/howpeople1/ ] 25.9.2003.

Haatainen, E. ja Korhonen, K. (2002). Guidelines for teacher training and technical and pedagogical support. Itcole teacher training and consulting model. A report for the European Commission, ITCOLE Project, IST-200026249. [http://www.euro-cscl.org/site/itcole/ D8_1_guidelines_for_teach.pdfl2.2.2004.

Hakkarainen, K. ja Järvelä, S. (1999). Tieto- ja viestintätekniikka asiantuntijaksi oppimisen tukena. Teoksessa: Eteläpelto, A. ja Tynjälä, P. (toim.) Oppiminen ja asiantuntijuus, 241-256.

Hakkarainen, K., Lonka, K. ja Lipponen, L. (2000). Tutkiva oppiminen - Älykkään toiminnan rajat ja niiden ylittäminen.WSOY.

Hakkarainen, K. (2001). Aikuisen oppiminen verkossa. Teoksessa Sallila, P. ja Kalli, P. (toim.) Verkot ja teknologia aikuisopiskelun tukena. Aikuiskasvatuksen 42. vuosikirja. Kansanvalistusseura ja Aikuiskasvatuksen Tutkimusseura, 16-52.

Hakkarainen, K., Paavola, S. ja Lipponen, L. (2003). Käytäntöyhteisöistä innovatiivisiin tietoyhteisöihin. Aikuiskasvatus 1, 4-13.

Hakkarainen, K. 2003. Tieteellinen kognitio, kulttuurinen oppiminen ja tiedon yhteisöllinen tuottaminen. Kasvatus, 34, 1, 5-17.

Hargreaves, A., Earl, L., Moore, S. ja Manning, S. (2001). Learning to Change. Teaching Beyond Subjects and Standards. San Francisco: Jossey-Bass A Wiley Company.

Järvinen, A. (1990). Reflektiivisen ajattelun kehittyminen opettajankoulutuksen aikana. Jyväskylän yliopisto. Kasvatustieteiden tutkimuslaitoksen julkaisusarja A. Tutkimuksia 35.

Järvinen, A. (1999). Opettajan ammatillinen kehitysprosessi ja sen tukeminen. Teoksessa Eteläpelto, A. ja Tynjälä, P. (toim.) Oppiminen ja asiantuntijuus, 258-274.

Koivisto, J., Kylämä, M., Listenmaa, J.ja Vainio, L. (2002). Virtuaaliopetuksen haasteet ja niihin vastaaminen. Malleja ja menetelmiä opetushenkilöstön osaamistarpeiden ennakointiin virtuaaliopetuksessa yliopistoissa ja ammattikorkeakouluissa. VirtuaaliOTE-projektin loppuraportti 28.2.2002. Opetusministeriö. ESR -projekti nro 81502.

Korhonen, V. (2003). Oppimisen kontekstuaalisuutta tunnistamassa. Aikuisopiskelijan oppimiseen kytkeytyvät kontekstit verkkopohjaisessa opiskelussa. Aikuiskasvatus 3, 204213.

Lakkala, M., Lallimo, J., ja Rahikainen, M. (2003). Teachers' conceptions and practices in organising and scaffolding computer-mediated inquiry. A paper presented at the symposium titled: 'Implementing a pedagogically meaningful electronic learning environment in four different European school contexts'. The 10th Biennial EARLI Conference, August 26-30, 2003, Padova, Italy.

Launis, K. ja Engeström, Y. (1999). Asiantuntijuus muuttuvassa työtoiminnassa. Teoksessa Eteläpelto, A. ja Tynjälä, P. (toim.) Oppiminen ja asiantuntijuus. WSOY, 48-63.

Lauriala, A. (2000). Opettajan ammatillinen uu- 
distuminen: sosiokulttuurinen näkökulma opettajan oppimiseen. Teoksessa Harra, K. (toim.) Opettajan professiosta. OKKA-säätiön vuosikirja 2000. 88-97.

Lipponen, L. (1997). Tietotekniikka yhteisöllisen oppimisen tukena. Teoksessa Tella, S. (toim.) Media nykypäivän koulutuksessa. Osa 1. Helsingin yliopisto Opettajankoulutuslaitos. Tutkimuksia 178, 99-107.

Lipponen, L. ja Hakkarainen, K. (1998). Tiedonmuodostus verkostopohjaisessa oppimisympäristössä. CSILE-projekti. Helsingin kaupungin opetusviraston julkaisusarja A6: 1998.

Lipponen, L. (2002). Esimerkkejä tiedonrakentelun käytännöistä. Teoksessa Ilomäki, L. (toim.) Tietotekniikka koulun arjessa. Loppuraportti Helsingin kaupungin opetustoimen tietotekniikkaprojektista 1996-2000, 90-94.

Luque, M-L. (2003). The role of domain-specific knowledge in intentional conceptual change. Teoksessa Sinatra, G. M. ja Pintrich, P.R. (toim.) Intentional Conceptual Change. Mahwah, NJ: Lawrence Erlbaum Associates, 133-170.

Mahlamäki-Kultanen, S. (2001). Ongelmalähtöinen oppiminen verkkoympäristössä. Teoksessa Honka, J., Lehtinen, M. ja Honka, U. (toim.) Ammattikasvatuksen uudet tuulet. Vaikutteita AERA 2001 Konferenssista, 18-25.

Mezirow, J. (1996). Uudistava oppiminen. Helsingin yliopiston Lahden tutkimus- ja koulutuskeskus.

McConnell, D. (2001). Action Research and Distributed Problem Based Learning in Continuning Professional Education. Paper presented at the Annual Meeting of the AERA 2001. Seattle.

Nevgi, A. ja Tirri, K. (2001). Oppimista edistävät ja estävät tekijät verkko-opiskelussa. Teoksessa Sallinen, P. ja Kalli, P. (toim.) Verkot ja teknologia aikuisopiskelun tukena. Aikuiskasvatuksen 42. Vuosikirja. Kansanvalistusseura ja Aikuiskasvatuksen Tutkimusseura, 99-117.

Ojanen, S. (1998). Työyhteisön kehittämisen reunaehdot. Teoksessa Luukkainen, O. (toim.) Tulevaisuuden tekijät. Uuden opettajuuden mahdollisuudet. WSOY, 223-236.

Orrill, C. H. (2001). Supporting Online PBL: Design Considerations for Collaborative
Problem-Solving Communication Tools. Paper presented at the Annual Meeting of the AERA 2001. Seattle.

Poikela, S. (2003). Ongelmaperustaisesta pedagogiikasta. Aikuiskasvatus 3, 219-221.

Rajala, R. (2002). Jaksamista ja hyvinvointia. Kasvatus 33 (3), 223-225.

Ruohotie, P. (2000). Oppiminen ja ammatillinen kasvu. WS Bookwell oy.

Ruohotie, P. (2003). Mitä on ammatillinen huippuosaaminen? Ammattikasvatuksen aikakauskirja 1. 4-11.

Ryymin, E. ja Korhonen, K. (2003). The Teacher Training and Consulting Model. Deliverable 8.1. Innovative Technologies for Collaborative Learning and Knowledge Building. ITCOLE IST Project 26249. Summary. [http://ww.eurocscl.org/site/itcole/itcole_training_consulting. pdf] 2.2.2004.

Scardamalia, M. ja Bereiter, C. (1992). An architecture for collaborative knowledge building. Teoksessa Verschaffel, L. (toim.) Computerbased learning environments and problem solving. Berlin: Springer-Verlag, 41-66.

Scardamalia, M. ja Bereiter, C. (1994). Computer support for knowledge building communities. The journal of the Learning Sciences, 3, 265-283.

Scardamalia, M., Bereiter, C., McLean, R., Swallow, J. ja Woodruff, E. (1989). Computer-supported intentional learning environments. Educational Computing Research, 5, 51-68.

Tella, S., Vahtivuori, S., Vuorento, A., Wager, P. ja Oksanen, U., (2001). Verkko opetuksessaopettaja verkossa. Edita.

Vahtivuori, S., Wager, P. ja Passi, A. (1999). ”Opettaja, opettaja teletiimi ‘Tellus' kutsuu...” Kohti yhteisöllistä opiskelua virtuaalikoulussa. Kasvatus 30, (3), 265-278.

Vygotsky, L. S. (1987). Mind in Society: the development of higher psychological processes. MA Harvard University Press.

Wenger, W. (1998). Communities of Practice: Learning, Meaning and Indentity. Cambridge University Press.

Kirjoituksessa mainittu opettajien verkko-oppimisen täydennyskoulutus- ja konsultointimalli toteutettiin Helsingin opetusviraston mediakeskuksessa ensimmäisen kerran vuosina 2001-2002. Koulutukseen osallistui ala-asteen, yläasteen ja lukion opettajia yleis- ja erityisopetuksesta. 